\title{
Radioactivity of Estonian groundwater and technology for its removal
}

\author{
L. Lumiste ${ }^{1}$, R. Munter ${ }^{1}$, J. Sutt ${ }^{2}$, T. Kivimäe ${ }^{2} \&$ T. Eensalu ${ }^{3}$ \\ ${ }^{I}$ Chemical Engineering Department, \\ Tallinn University of Technology, Estonia \\ ${ }^{2}$ Water Technology Partners Ltd., Estonia \\ ${ }^{3}$ Viimsi Water Ltd., Estonia
}

\begin{abstract}
The purpose of this work has been to elaborate a cost-effective and relatively simple technology for groundwater simultaneous purification from iron, manganese, sulfides, ammonia, and some radionuclides $\left(\mathrm{Rn}^{222}, \mathrm{Ra}^{226}, \mathrm{Ra}^{228}\right)$. A pilot plant consisting of the Venturi-type aeration unit GDT (Gas-Degas Technology, Mazzei Corp. USA), an oxidation tank and two-stage filtration columns was constructed. Different non-catalytic (Everzit Special Plus, sand etc.) and catalytic filter materials (Filtrasorb FMH, Pyrolox etc.) as well as zeolites were tested. It was found that intensive aeration of groundwater, followed by oxidation with certain contact time, and appropriate selection of filter materials of different properties, enable removal of radium isotopes together with iron and manganese. Total effectiveness of the process was $90 \%$ removal of gross-alfa and $70-75 \%$ removal of gross-beta activity of groundwater. The total average effective dose was calculated by residual $\mathrm{Ra}^{226}$ and $\mathrm{Ra}^{228}$, and was about $0.07 \mathrm{mSv} / \mathrm{yr}$, which meets the EU DWD requirement $(0.1 \mathrm{mSv} / \mathrm{yr})$. On the basis of the results of the pilot plant studies, a full scale plant $\left(2500 \mathrm{~m}^{3} / \mathrm{d}\right)$ of Viimsi Water Ltd. was designed by the SWECO Project. The plant will be put into operation in January 2012.

Keywords: groundwater, iron, manganese, radium isotopes, aeration, filtration, adsorption.
\end{abstract}




\section{Introduction}

\subsection{Technology for radionuclides removal}

The WEKNOW (Web-based European Knowledge Network on Water) investigation (2005) revealed increased radionuclides content in groundwater of 18 European countries: Austria, Bulgaria, Czech Republic, Germany, Spain, France, Finland, Greece, Ireland, Italy, Hungary, Sweden, Slovakia, Slovenia, Luxemburg, Portugal, Poland, and Estonia [1]. 35\% of drinking water in Estonia originates from surface water (cities Narva and Tallinn), 37\% is groundwater from deep wells, and the remaining part comes from small draw wells [2].

Systematic studies on groundwater radioactivity in Estonia were started in 1994-1998, followed by some recent complementary studies in 2001-2009 [3, 4]. Radioactivity of groundwater (mostly in the northern bank of Estonia) is caused by natural radionuclides penetrating into the groundwater aquifer from the surrounding layers of soil, e.g. obolus sandstone and dictyonema oil shale. The radioactive elements mainly affect the water of Cambrian-Vendian and Ordovician-Cambrian aquifers. Based on the information provided by Estonian authorities, the radioactivity is mainly due to the presence of ${ }^{226} \mathrm{Ra}$ (alphaemitter) and ${ }^{228} \mathrm{Ra}$ (beta-emitter). It was established that for $70 \%$ of wells in Cambrian-Vendian water layer the activity index (I) was higher than 1.0. It means that the water consumption of $2 \cdot 10^{-3} \mathrm{~m}^{3} /$ day will lead to the higher total indicative dose than established by European Directive 98/83/EC (0.1 mSv/year). Approximately $50 \%$ of monitored population in Estonia uses drinking water exceeding this reference level.

Radium is present in water in the form of a large "hydrophobic" cation and can be removed by strong acid cationite (SAC). Uranium is in the common range of $\mathrm{pH}=6-8$ present in the form of anion $\mathrm{UO}_{2}\left(\mathrm{CO}_{3}\right)_{2}{ }^{2-}$, and consequently, should be removed by anion exchange through strong basic anionite (SBA) [5, 6]. An alternative to ion exchange process is reverse osmosis [7]. Significant disadvantages of both processes along with the relatively high costs are the requirement of the raw groundwater proper pretreatment to remove iron, manganese, hardness, organics, etc as the compounds causing ionite inactivation and membrane fast fouling. Furthermore, application of ion exchange is accompanied by the periodic discharge of salted radioactive regeneration solutions, and reverse osmosis, even worse - by continuous discharge of highly salted radioactive retentate (15-25\% of the input).

The selection of groundwater treatment processes depends on the raw water quality. A typical flow sheet consists of a pre-aeration (pre-oxidation) stage followed by filtration/adsorption and post-disinfection stages. Some very interesting studies $[8,9]$ have pointed to the possibilities for radium removal from groundwater involving more economical ways than ion exchange and reverse osmosis - by natural separation processes of dissolved iron and manganese or even by external formation of hydrous manganese oxide (HMO) or by using catalytic filtration materials containing $\mathrm{MnO}_{2}$. However, the studies carried out recently in the framework of Estonian-Italian cooperation [3] 
revealed that at existing treatment plants the radium removal together with the conventional $\mathrm{Fe} / \mathrm{Mn}$ separation processes did not exceed $30 \%$.

The main aim of the present pilot-scale study has been to elaborate an economical and possibly chemical- free technology for radium removal from iron and manganese containing groundwater using aeration, oxidation and adsorption/filtration processes as well as to collect the preliminary information about the possible options for liquid and solid waste management.

\section{Materials and methods}

\subsection{The basic hypotheses of the study}

At the planning stage of the pilot scale tests, we started from the following hypotheses: 1) it is possible to significantly improve radium removal degree over $30 \%$ together with ferric hydroxide and hydrous manganese flocks due to the coprecipitation and adsorption by intensive aeration and oxidation process optimation; 2) radium cations adsorption onto solid $\mathrm{MnO}_{2}$ containing catalytic filter materials is the more reasonable and cheaper way for their removal compared to the $\mathrm{HMO}$ process, where chemicals $\left(\mathrm{KMnO}_{4}\right.$ and $\mathrm{MnSO}_{4}$ solutions) are continuously added.

Ferrous iron $\left(\mathrm{Fe}^{2+}\right)$ is oxidized to ferric iron $\left(\mathrm{Fe}^{3+}\right)$, which readily forms the insoluble iron hydroxide complex $\mathrm{Fe}(\mathrm{OH})_{3}$. For example, iron oxidation by dissolved oxygen of air [10]:

$$
4 \mathrm{Fe}\left(\mathrm{HCO}_{3}\right)_{2}+2 \mathrm{H}_{2} \mathrm{O}+\mathrm{O}_{2}=4 \mathrm{Fe}(\mathrm{OH})_{3}+8 \mathrm{CO}_{2}
$$

The oxidation rate depends on $\mathrm{pH}$, alkalinity, organic content, and oxidant concentration. In spite of the fact that ferric iron complexes in water are charged positively, their large flocks can also remove some positively charged radium cations as a result of sweep coagulation. Radium cations removal degree depends on iron initial concentration, alkalinity, $\mathrm{pH}$, TDS, and other parameters of water matrix $[8,9]$.

Manganese $\left(\mathrm{Mn}^{2+}\right)$ is oxidized after aeration to $\left(\mathrm{Mn}^{4+}\right)$, which forms $\mathrm{Mn}(\mathrm{OH})_{4}$ and further insoluble $\mathrm{MnO}_{2}$ [11]. According to research information [12], hydrous manganese oxide particles $\left(\mathrm{Mn}(\mathrm{OH})_{4}\right)$ created after divalent manganese oxidation in water form in neutral, and especially, in basic media negatively charged flocks which should possess higher potential for radium cations removal than the ferric hydroxide flocks. All oxidation reactions (with air, ozone, permanganate, chlorine etc.) liberate $\mathrm{CO}_{2}$ which together with the gases $\left(\mathrm{CO}_{2}, \mathrm{Rn}, \mathrm{CH}_{4}, \mathrm{H}_{2} \mathrm{~S}\right.$ etc.) initially dissolved in groundwater may cause serious problems in filter bed operation and must be properly removed before filtration.

Contemporary methods of iron, manganese and hydrogen sulfides removal are mainly based on catalytic filter materials containing $\mathrm{MnO}_{2}$ (Birm, Manganese Greensand, Filox, Pyrolox, FMH, Everzit-Mn et al.). In the oxidation/reduction 
reaction, $\mathrm{MnO}_{2}$ is reduced to $\mathrm{MnO}$, and ferrous iron is oxidized to ferric iron forming ferric hydroxide, which is precipitated [10]:

$$
2 \mathrm{Fe}\left(\mathrm{HCO}_{3}\right)_{2}+\mathrm{MnO}_{2}+\mathrm{H}_{2} \mathrm{O}=2 \mathrm{Fe}(\mathrm{OH})_{3}+\mathrm{MnO}+4 \mathrm{CO}_{2}+\mathrm{H}_{2} \mathrm{O}
$$

Manganese dioxide works most efficiently at a $\mathrm{pH}$ of 6.5 to 9.0. It should not be used on waters that have bacterial or organic iron. It was expected that adsorption of radium cations onto $\mathrm{MnO}_{2}$ layer of the catalytic filter materials can serve as a third option for radium removal, which can be easily optimized by selection of 2-3 catalytic filter layers with increasing $\mathrm{MnO}_{2}$ content downflow in the filtration process.

Thus, our study was focused on the optimation of the groundwater pilot plant flow sheet for iron, manganese and radium simultaneous removal, consisting of the stages of aeration, oxidation and filtration/catalytic filtration, varying the dissolved oxygen concentration, residence time for oxidation, number and composition of the I and II stage filter materials (including thickness of layer, diameter of particles, contact time, etc.).

\subsection{Experimental set-up}

Pilot plant studies were carried out with Viimsi WTP (6 km from Tallinn city) raw groundwater. Iron, manganese, ammonia and radionuclides initial contents exceeded the requirements of the EU DWD [1] (MPC are in brackets) correspondingly: $0.1-2.6 \mathrm{~g} / \mathrm{m}^{3}(0.2) ; 0.004-0.183 \mathrm{~g} / \mathrm{m}^{3}(0.05) ; 0.07-1.4 \mathrm{~g} / \mathrm{m}^{3}$ $(0.5)$, and $0.08-0.73 \mathrm{mSv} /$ year $(0.1)$. The flow sheet $\left(\mathrm{Q}=3 \mathrm{~m}^{3} / \mathrm{h}\right)$ consisted of a pre-aeration unit GDT (Gas-Degas Technology) with injector, an intermediate oxidation tank to provide needed residence time (1-2 min) for iron, and especially, for manganese oxidation, centrifugal degas separator, and one or two filtration columns $(\mathrm{D}=0.180 \mathrm{~m} ; \mathrm{H}=2.2 \mathrm{~m})$ with catalytic filter materials (Fig. 1).

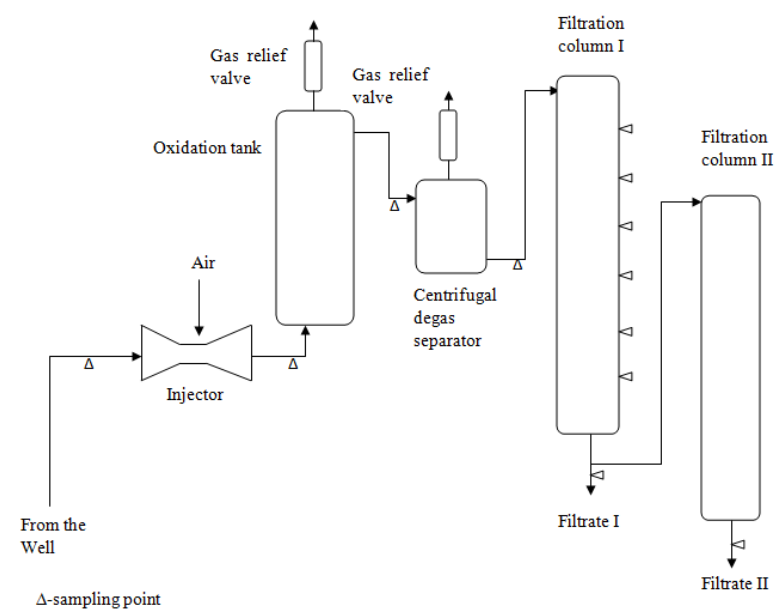

Figure 1: $\quad$ Pilot plant flow sheet. 
Different filter materials (Table 1) were tested during pilot studies; variations were made in sequence and heights. The following configuration of materials gave the best results:

- Filtration column I: Filtersorb ${ }^{\circledR} \mathrm{FMH} h=1 \mathrm{~m}$; Pyrolox $^{\mathrm{TM}} \mathrm{h}=0.3 \mathrm{~m}$

- Filtration column II: Zeolith $\mathrm{N} \mathrm{h=1.1} \mathrm{m}$

Table 1: $\quad$ Filter materials used during pilot plant studies.

\begin{tabular}{|l|l|c|c|c|}
\hline Material & Composition & $\begin{array}{l}\text { Density, } \\
\mathrm{kg} / \mathrm{m}^{3}\end{array}$ & $\begin{array}{l}\text { Particle } \\
\text { size, } 10^{3} \mathrm{~m}\end{array}$ & Bed height, $\mathrm{m}$ \\
\hline $\begin{array}{l}\text { Filtersorb } \\
\text { FMH }\end{array}$ & $\begin{array}{l}\mathrm{MnO}_{2} \text { coated } \\
\text { dolomite }\end{array}$ & 1560 & $0.8-1.26$ & 1.0 \\
\hline $\begin{array}{l}\text { Everzit Special } \\
\text { Plus }\end{array}$ & $92 \%$ carbon & 1300 & $0.8-2.0$ & 0.8 \\
\hline Zeolith N & $\begin{array}{l}\text { Natural } \\
\text { zeolith, up to } \\
72 \% \mathrm{SiO}_{2} \text { and } \\
\text { up to } 13 \% \\
\mathrm{Al}_{2} \mathrm{O}_{3}{ }^{*}\end{array}$ & $\begin{array}{c}1600- \\
1800\end{array}$ & $1.0-2.5$ & 1.1 \\
\hline Pyrolox & Natural $\mathrm{MnO}_{2}$ & 1900 & $0.2-0.4$ & $0.3-0.6$ \\
\hline
\end{tabular}

This configuration enabled us to achieve water quality that meets the requirements of the EU DWD already in one filter only, leaving the second filter for "polishing step". The pilot plant was constructed to enable possible changes in the order of technological steps and flow rates of air and water. The flow sheet mentioned in the previous paragraph gave the best results. The groundwater was pumped through the injector at the rate of $2.5 \mathrm{~m}^{3} / \mathrm{h}$, to achieve air and water ratio 2-6 $\mathrm{m}^{3}$ (air) $/ \mathrm{m}^{3}$ (water), and enable the GDT separator operate at maximum degas regime.

To promote better gas removal, an oxidation tank (a contact column with alterable volume) was installed after the injector. The volume of oxidation tank was altered between 0.047 and $0.094 \mathrm{~m}^{3}$ (contact time varied between 1.2 and $2.4 \mathrm{~min})$. As a result of tests, contact time of $1.2 \mathrm{~min}$ was found optimal. Aerated water was filtered at the rate of $0.2 \mathrm{~m}^{3} / \mathrm{h}$ (maximum filtration rate 10 $\mathrm{m} / \mathrm{h}$ ) while the rest of the water was channeled.

In addition to filtrate quality monitoring, some water parameters were determined in different points of the pilot plant. Samples were taken from the well, after the injector, after the oxidation tank, after the degas separator, from the filter bed (from various heights) and from filtrate I and filtrate II to measure temperature, $\mathrm{pH}$, dissolved oxygen (electrode Marvet Junior 156), and dissolved carbon dioxide (HACH colorimetric express method, phenolphtalein and $\mathrm{NaOH}$ solution). In the case of filtrate I and filtrate II, important physical and chemical 
parameters, such as colour, turbidity, total iron, manganese and ammonia were measured spectrophotometrically as well.

Radioactivity of water samples (gross-alpha and gross-beta activity in Bq/L) was determined by the Estonian Radiation Centre (liquid scintillation counting method). Forte et al. [3] pointed out that $>90 \%$ of expected effective radiation dose in Estonian Cambrian-Vendian groundwater is caused by $\mathrm{Ra}^{226}$ and $\mathrm{Ra}^{228}$. To ensure the effective dose assessment accuracy, $\mathrm{Ra}^{226}$ and $\mathrm{Ra}^{228}$ contents in filtrate I and filtrate II were also determined in the Estonian Radiation Centre (liquid scintillation counting and $\gamma$-spectrometry). Effective annual doses were calculated from WHO recommendations [13].

Filters were backwashed with raw water once a week; flow rates were chosen according to filter materials. Backwash waters were collected and radionuclides content was measured from the sludge and water separately. Results indicate that no additional treatment of backwash water is necessary. Also, the radioactivity of the filter bed, which has been in operation for about a month, was checked using scanning electron microscopy. No traces of radium fixed to the grains were discovered, i.e. the radium bound to the iron hydroxide and manganese dioxide flocks was actually removed together with them during filter backwash.

\section{Results and discussion}

Ferrous iron $\left(\mathrm{Fe}^{2+}\right)$ was oxidized to ferric iron $\left(\mathrm{Fe}^{3+}\right)$, which readily formed the insoluble iron hydroxide complex $\mathrm{Fe}(\mathrm{OH})_{3}$. These flocks formed a blockage which increased with time. In addition, insoluble gases (injected excess air and liberated carbon dioxide during oxidation reactions) accumulated in the filter bed, but were released when forming larger bubbles. After 48 hours of continuous work, accumulation of gases stopped and the pressure drop remained almost constant. It gave us a reason to believe that the saturation level in gas accumulation was achieved. Still, we could register pressure drop increasing at the top layer of the filter media in filter I (70-260 $\mathrm{mm}$ from the surface), which represented $\mathrm{Fe}(\mathrm{OH})_{3}$ accumulation.

The dissolved oxygen in raw well water was less than $2 \mathrm{~g} / \mathrm{m}^{3}$. Fast saturation with oxygen of air was achieved in the Venturi-injector, where dissolved oxygen reached above $8 \mathrm{~g} / \mathrm{m}^{3}$. In the oxidation and filtration step, the concentration decreased being around $6-7 \mathrm{~g} / \mathrm{m}^{3}$ in the filtrate, whereas dissolved carbon dioxide concentration increased due to the oxidation, but then again demerged from the liquid phase, forming gas blockage in the filter bed.

Figure 2 illustrates changes in the ammonia, total iron and manganese content in the two-stage filtration system.

Overall removal of radioactivity is shown in Fig. 3. The co-precipitation process, where $\mathrm{Mn}(\mathrm{OH})_{4}$ and $\mathrm{Fe}(\mathrm{OH})_{3}$ flocks played an essential role, resulted in radionuclides removal [14]. During $\mathrm{Fe}(\mathrm{OH})_{3}$ formation, "hydrophobic" $\mathrm{Ra}$ cations associated with charged ferrous ions and ferrous intermediates formed a precipitate. 


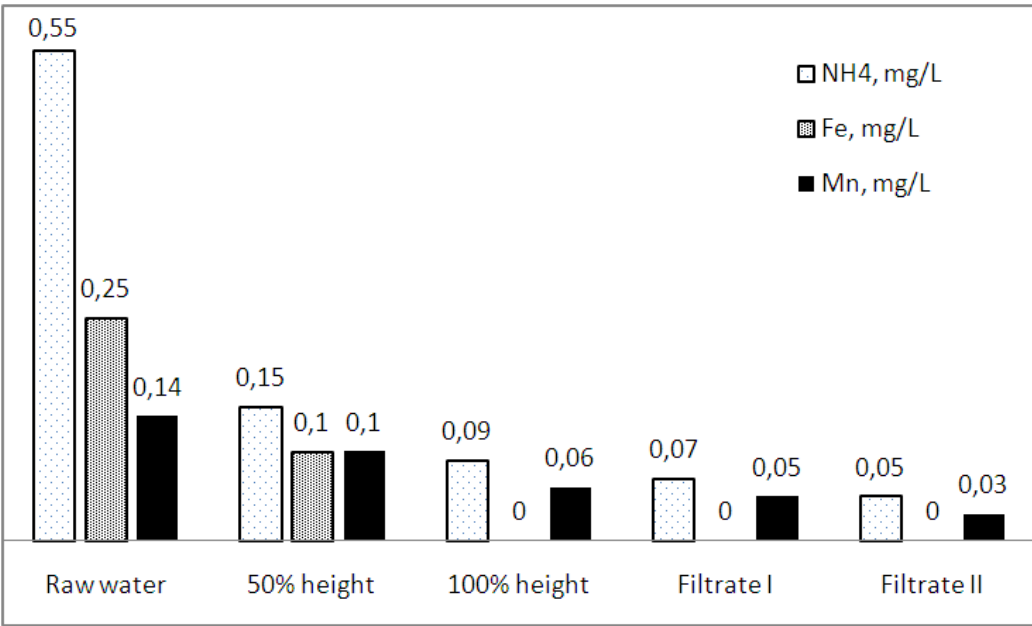

Figure 2: Changes in the ammonia, total iron and manganese content in the two stage filtration system.

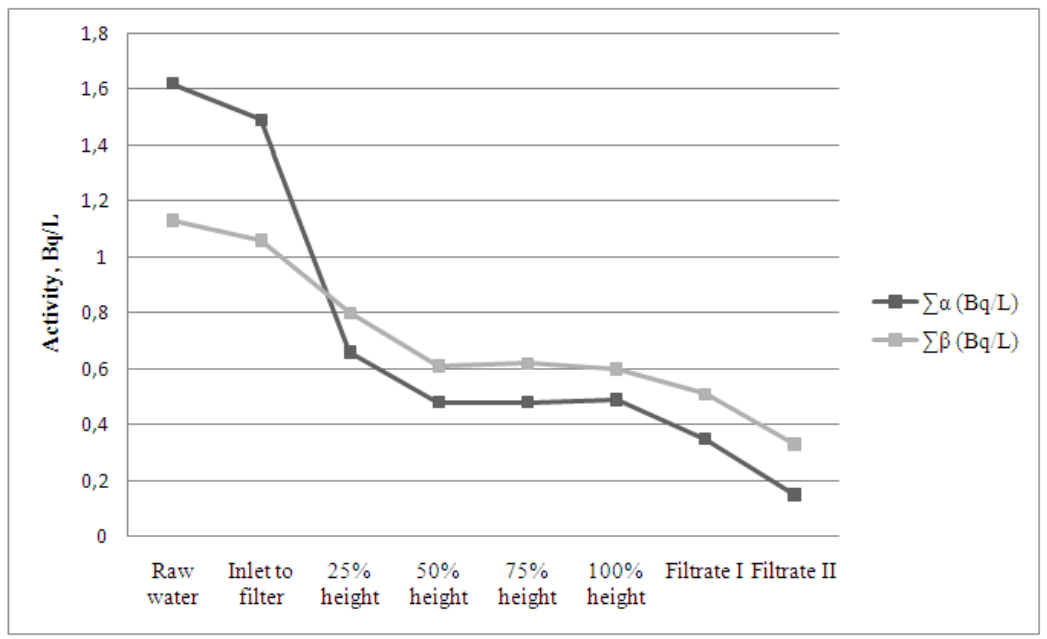

Figure 3: Changes in radioactivity of water.

The second mechanism is believed to be the adsorption of radium cations onto $\mathrm{Fe}(\mathrm{OH})_{3}$ flocks and $\mathrm{MnO}_{2}$ grains. Water radioactivity and iron were removed concurrently during filtration and precipitated in backwash water, which was of clearly higher radioactivity and proved iron, manganese and radionuclide simultaneous removal. Patel and Clifford [9] have found that adsorption onto $\mathrm{Mn}(\mathrm{OH})_{4}$ was more effective than onto $\mathrm{Fe}(\mathrm{OH})_{3}$, but since in our case the well water natural $\mathrm{Fe}^{2+}$ content was significantly higher than manganese content; pilot studies mainly demonstrated the importance of $\mathrm{Fe}(\mathrm{OH})_{3}$ in the radionuclide 
removal mechanism. Even if co-precipitation with $\mathrm{Mn}(\mathrm{OH})_{4}$ and $\mathrm{MnO}_{2}$ is more effective, it is reasonable to make use of natural iron available in raw water, which also has to be removed.

$70 \%$ of gross-alpha and $45 \%$ of gross-beta activity was removed in the top layer of filter I (400 mm), most of the iron (72\%) was removed as well. In filter II $55 \%$ of gross-alpha and $35 \%$ of gross-beta activity was removed compared to filtrate I. Total effectiveness was $90 \%$ removal of gross-alfa and $70 \%$ removal of gross-beta activity. Gross-beta activity includes $\mathrm{K}^{40}$ (in Estonian groundwater average $0.24 \mathrm{~Bq} / \mathrm{L}$ [3], which was not taken into account in the total effective dose calculation, since it does not accumulate in human tissue. Since uranium content in our well water was marginal, and radon was almost totally (99\%) removed in the degas separator, the total effective dose was calculated by $\mathrm{Ra}^{226}$ and $\mathrm{Ra}^{228}$ and was about $0.07 \mathrm{mSv} / \mathrm{a}$.

The theoretical assumption that radionuclides are already removed with $\mathrm{Fe}(\mathrm{OH})_{3}$ flocks in the first filtration step was verified by examining wash water. The radioactivity of wash water containing precipitate and that of the filtered wash water was measured. The results showed 4.6 times higher gross-alpha and 5.3 times higher gross-beta activity in water containing precipitate. Removal of radionuclides was obviously achieved simultaneously by three different mechanisms: co-precipitation with iron hydroxide flocks, adsorption onto in situ formed manganese dioxide and filtration through $\mathrm{MnO}_{2}$ layered filter material. There was no need to apply the $\mathrm{HMO}$ process (dosing of $\mathrm{KMnO}_{4}$ and $\mathrm{MnSO}_{4}$ ).

\subsection{Waste management}

Radionuclides removal from water creates gaseous (desorbed radon), liquid (backwash water from filters, ionites regeneration solutions, brine from RO systems) and solid (spent filter materials or resins, spent membranes) wastes.

Liquid wastes, i.e. backwash water, was analyzed by us to ensure the compliance to EU directive. Backwash waters from two filtration steps were collected and analyzed separately. Preliminary measurements of gross-alfa and gross-beta are shown in Table 2. The range of results is wide due to the presence of precipitate in the samples, since radium is bound to $\mathrm{Fe}(\mathrm{OH})_{3}$ flocks. The results show clearly that the majority of radionuclides is removed with precipitate.

Table 2: $\quad$ Gross-alpha and gross-beta of backwash water.

\begin{tabular}{|c|c|c|}
\hline Backwash water & Gross-alpha & Gross-beta \\
\hline Filter colomn I & $1.4-6.3$ & $2.4-12.8$ \\
\hline Filter column II & $1.36-1.77$ & $2.75-3.31$ \\
\hline
\end{tabular}

In addition, $\mathrm{Ra}^{226}$ and $\mathrm{Ra}^{228}$ activities were measured (Table 3 ) and the compliance to clearance level was calculated on that basis. According to the EU 
directive, if the waste contains more than one radionuclide, the summation formula can be used:

$$
\sum_{i=1}^{n} \frac{C_{i}}{C L i} \leq 1.0
$$

where:

$C_{\mathrm{i}}$ is the total activity in the structure per unit mass of radionuclide $C(\mathrm{~Bq} / \mathrm{g})$,

$C_{\mathrm{Li}}$ is the clearance level of radionuclide $L(\mathrm{~Bq} / \mathrm{g})$,

$n$ is the number of radionuclides in the mixture.

Using Eqn. (3) and data from Table 3, the compliance to clearance level was calculated, which verifies that liquid wastes can be discharged directly to sewerage:

$$
\frac{0.00058}{0.01}+\frac{0,00267}{0.01}=0.325
$$

Table 3: $\quad \mathrm{Ra}^{226}$ and $\mathrm{Ra}^{228}$ concentration in backwash water.

\begin{tabular}{|c|c|c|}
\hline Radionuclide & Clearance level, $\mathrm{Bq} / \mathrm{g}$ & Activity, $\mathrm{Bq} / \mathrm{g}$ \\
\hline $\mathrm{Ra}-226$ & 0.01 & 0.00058 \\
\hline $\mathrm{Ra}-228$ & 0.01 & 0.00267 \\
\hline
\end{tabular}

Regarding to the solid radioactive wastes of water treatment, spent filter and ion exchange materials represent a special type of radioactive waste and pose unique problems in the selection of their treatment options [15]. Although preliminary tests indicate that no radium is accumulated in the filter material, further investigation is needed. If filter material radioactivity poses a problem, the best solution here is probably incorporating these into a matrix material (cement, bitumen, polymer etc.) for solidification or directly into a storage and/or final disposal container.

\section{Conclusions}

This study was focused on the optimization of the groundwater pilot plant treatment scheme for iron, manganese, ammonia and sulfides removal, and contained the stages of aeration, oxidation and filtration/catalytic filtration, while varying the dissolved oxygen concentration, residence time for oxidation and filtration, number and composition of the I and II stage filter materials (incl. thickness of layer, diameter of particles, etc.). Ferrous iron $\left(\mathrm{Fe}^{2+}\right)$ was oxidized to ferric iron $\left(\mathrm{Fe}^{3+}\right)$, and divalent manganese $\left(\mathrm{Mn}^{2+}\right)$ to hydrous manganese oxide $\left(\mathrm{Mn}(\mathrm{OH})_{4}\right)$ and further to $\mathrm{MnO}_{2}$. The co-precipitation process, where $\mathrm{Mn}(\mathrm{OH})_{4}$ and $\mathrm{Fe}(\mathrm{OH})_{3}$ flocks played an essential role, resulted in simultaneous radium isotopes removal. Co-precipitation of radium with $\mathrm{Mn}(\mathrm{OH})_{4}$ was more effective than with $\mathrm{Fe}(\mathrm{OH})_{3}$. In the case of water with higher radioactivity, the second (last) stage of the process can be adsorption of $\mathrm{Ra}^{2+}$ onto $\mathrm{MnO}_{2}$ containing surface of the catalytic filter material or application of zeolites. Detention time of water in the oxidation tank played a key role in chemical reactions 
implementation and gas $\left(\mathrm{CO}_{2}\right)$ removal to avoid sharp increase in the pressure drop of the filters. The total effectiveness of the described technology was $90 \%$ removal of gross-alpha and $70 \%$ removal of gross-beta activity. To protect rights to the technology, applications for an Estonian patent (P201000052) and international patent (PCT/EP2010/061529) have been presented.

\section{Acknowledgements}

Financial support from Enterprise Estonia (project EU32691 "Novel technology of water purification") and state budget the SF0140002s12 "Water and soil protection from the priority and emerging micropollutants with advanced oxidation technologies" support are greatly appreciated. We also thank the Head of the Materials Research Center of TUT, Dr. Urve Kallavus, for analyses of the filter materials.

\section{References}

[1] WEKNOW. Hulsmann, A., Radioactivity in European Drinking Water and Sources Designated for the production of drinking water. June, 2005.

[2] Savitski, L., Otsa, E. and Tamm, I., Estonian Environmental Monitoring. Tallinn, 1997 (in Estonian).

[3] Forte, M., Airoldi, R., Caldognetto, E., Realini, F., Rusconi, R., Trotti, F., Component 1 - Technical Report. Estimation of concentrations of radionuclides in Estonian groundwaters and related health risks. Twinning Light Contract No. EE06-IB-TWP-ESC-03. Tallinn, Estonia, April, 2009.

[4] Forte, M., Airoldi, R., Caldognetto, E., Realini, F., Rusconi, R., Trotti, F., Component 2 - Technical Report. Estimation of concentrations of radionuclides in Estonian groundwaters and related health risks. Twinning Light Contract No. EE06-IB-TWP-ESC-03. Tallinn, Estonia, September, 2009.

[5] Hodi, M., Polyak, H., Hlavay, J., Removal of pollutants from drinking water by combined ion exchange and adsorption methods. Envir. Inter., 21, pp. 325-331, 1995.

[6] Camacho, L.M., Deng, S., Parra, R.R., Uranium removal from groundwater by natural clinoptilolite zeolite: effects of $\mathrm{pH}$ and initial feed concentration - J. Hazard. Mater., 175, pp. 393-398, 2010.

[7] Crittender, J.C., Water Treatment - Principles and Design. John Wiley \& Sons, New York, 2005.

[8] Valentine, R., Splinter, R., Mulholland, T., A study of possible economical ways of removing radium from drinking water, in: EPA Project Summary. EPA/600/S2-88/009, Cincinnati OH, USA, pp. 1-10,1988.

[9] Patel, R., Clifford, D., Radium removal from water by manganese dioxide adsorption and diatomaceous earth filtration, in: EPA Project Summary. EPA/600/S2-91/063, Cincinnati OH, USA, pp. 1-8,1992.

[10] Faust, S.D., Aly, O.M., Chemistry of water treatment. Lewis Publ., New York, 1998. 
[11] Sommerfeld, E.O., Iron and manganese removal handbook. AWWA, Denver, USA, 1999.

[12] Germain, D., Radium removal options for small systems: a comparison of processes, in: 3rd NSF International Symposium on small drinking water and wastewater systems, Washington DC, USA, April 22-25, pp. 57-66, 2001.

[13] WHO Guidelines for Drinking Water Quality. First addendum to third edition. Vol.1, Recommendations - 3rd (2006).

[14] Elejalde, C., Herranz, M., Idoeta, R., Legarda, F., Romero, F., Baeza, A., Retention of radium from thermal waters on sand filters and adsorbents, $J$. Hazard. Mater., 144, pp. 645-648, 2007.

[15] Hess, C.T., Michel J., Horton T.R., The occurrence of radioactivity in public water supplies in the United States. Health Physics, 1985, 48(3), pp. 553-586, 1985. 